\title{
NEW INITIATIVES: LITERATURE REVIEW MANUSCRIPTS AND THE APPOINTMENT OF ERNEST T. PASCARELLA AS AN ASSOCIATE EDITOR
}

\author{
John C. Smart*
}

The higher education research literature has increased dramatically in both size and complexity over the past four decades. Pascarella (2006) estimated, for example, that approximately 6,000-7,000 college impact studies alone have been conducted during this period. When one adds the many other domains of scholarly inquiry, the sheer size alone of the literature is staggering. The literature, however, has grown not only in terms of it size, but also in its complexity and sophistication, as evidenced by a much more diverse array of topics being addressed and reliance on theoretical frameworks from other disciplines to guide those inquiries. The literature has also become increasingly more diverse and sophisticated in terms of methodological approaches. Today's literature has a rich blend of both qualitative and quantitative methodological approaches, with growing sophistication in the specific forms of both methodological approaches.

Such developments are healthy manifestations of the continuing evolution of higher education from an emerging to a more mature academic discipline. The exceedingly more diverse, sophisticated, and fragmented character of the higher education research literature is but one consequence of this maturation process. Nonetheless, these same conditions may be seen as inhibiting future evolution by frustrating efforts toward the development of cumulative knowledge, a salient attribute of more mature areas of scholarly inquiry.

Research in Higher Education has contributed to the expanding higher education research literature since its founding in 1973. The journal is

\footnotetext{
*Address correspondence to: John C. Smart, Ph.D., College of Education, CEPR, 100 Ball Hall, The University of Memphis, Memphis, TN 38152-3570, USA. E-mail: jsmart@ memphis.edu
} 
thus reflective of the strengths and limitations manifested in that literature. So too do we have a responsibility to contribute to the further maturation of higher education as an area of scholarly inquiry by pulling together and synthesizing our increasingly disjointed research findings in order to establish a more solid foundation for future advances toward the development of cumulative knowledge. This obligation was noted by Pascarella (2006) who suggested that major journals in the field assume responsibility for this task by regularly devoting space to comprehensive literature reviews. I am pleased to announce that Research in Higher Education has enthusiastically accepted this responsibility and will make a concerted effort to solicit and publish manuscripts that synthesize and critique research findings on salient areas of inquiry in the field of higher education and that offer insights on needed conceptual and methodological developments that have the potential to advance the quality of research on those areas of inquiry.

We accept this responsibility with seriousness and enthusiasm, and our commitment to publishing first-rate syntheses of research findings is reflected in the appointment of Professor Ernest T. Pascarella as an Associate Editor of the journal to provide the essential leadership for this initiative. We hope this initiative will not only make syntheses available in a timelier manner, but also make them more accessible and easily digested by both policy makers and scholars.

Ernie Pascarella is well known to most of our readers since he is unquestionably one of the leading higher education scholars nationally and internationally. He holds the Mary Louise Petersen Endowed Chair in Higher Education and is co-director of the Center for Research on Undergraduate Education at the University of Iowa. He has authored nearly 200 journal articles and is the co-author (with Patrick T. Terenzini) of the two volumes of How College Affects Students (1991, 2005), which collectively provide a synthesis of the findings of approximately 5,000 studies focusing on the impact of colleges on students and student persistence in higher education. Professor Pascarella's research has been supported by numerous professional and governmental agencies, including the National Institute of Education, the National Science Foundation, the Mellon and Spencer Foundations, the American College Personnel Association, and the National Association of Student Personnel Administrators. The quality of his scholarship has been recognized by awards from the American Educational Research Association (Division J), Association for the Study of Higher Education, Association for Institutional Research, National Association of Student Personnel Administrators, International Reading Association, and the American College Personnel 
Association. Distinguished does not begin to capture his collective contributions to the field of higher education.

Literature review manuscripts will be handled in the same manner as all other manuscript submissions as described in the Instructions for Authors section of the journal website at www.springerlink.com. For example, authors should submit three hard copies of their manuscripts to me at my address on the journal website, I will then forward them to Professor Pascarella who will oversee their blind review by two or more established scholars and make a publication recommendation based on the results of the blind reviews of the manuscripts. Literature review manuscripts should generally run from 30 to 45 manuscript pages. This page constraint suggests that the manuscripts should provide in-depth syntheses of discernible, salient, and focused areas of inquiries rather than comprehensive reviews of research findings on more general and less clearly defined topics. Literature review manuscripts may be on any clearly identifiable and salient topic in the higher education research literature.

We are delighted that Professor Ernest T. Pascarella has accepted our invitation to provide the leadership for this initiative. We recognize the challenges ahead in making this initiative successful since literature syntheses are not a common form of scholarship in the higher education literature. Yet, these syntheses have the potential to contribute to the development of cumulative knowledge in our field, and thereby advance the maturity of higher education as a scholarly area of inquiry. We accept the challenge and encourage the submission of literature review manuscripts in an effort to make the journal an even more integral part of the higher education research literature.

\section{REFERENCES}

Pascarella, E. T. (2006). How college affects students: Ten directions for future research. J. College Student Dev. 47(5): 508-520.

Pascarella, E. T., and Terenzini, P. T. (1991). How college affects students, Jossey-Bass, San Francisco.

Pascarella, E. T., and Terenzini, P. T. (2005). How college affects students, Volume 2: A third decade of research, Jossey-Bass, San Francisco. 